\title{
CROSS-CURRENTS IN AUSTRALIAN TRADE UNIONISM
}

\author{
Les Cupper and June Hearn*
}

\section{INTRODUCTION}

In common with trade unions throughout the "western world", Australian unions entering the 1980 's have difficult times ahead. Grappling not only with the twin evils of high unemployment and inflation rates, but also with organizational structures ill-suited in many respects to cope with the technological revolution, Australian unions are reacting to the realities of today and attempting to anticipate the events of tomorrow. How effectively they are doing either may be gleaned to a large extent by an examination of their most recent deliberations in their "parliament" - the Australian Council of Trade Unions (ACTU) in September 1979 and surrounding issues and events.

This paper seeks to capture the mood and general thrust of current union deliberations in three major areas: (1) Organization and Structure; (2) Leadership and Ideology; (3) Policy issues. Some of what follows is of peculiarly Australian concern but much of it has wider ramifications highlighting some shared concerns of unionists the world over.

\section{ORGANISATION AND STRUCTURE}

Calls for rationalization of union structure have long been a feature of the Australian industrial scene. Unions, and the general public alike, are constantly reminded by a gaggle of industry, government, academic and union spokesmen of the need for amalgamation and the alleged benefits thereof. Arguably, these calls have fallen on deaf ears as few unions appear to have vigorously pursued policies of rationalization. To the authors' knowledge only five amalgamations have occurred in the federal jurisdiction in the past decade. ${ }^{1}$ Accordingly, Australia enters the $1980^{\prime}$ s boasting some 279 separate unions (for approximately 2.8 million unionists) $-60 \%$ of whom have less than 2000 members.

All too often, however, pronouncements on the need for amalgamation imply that mergers are something easily achieved. Nothing could be further from the truth. Federal-State and indeed, interstate branch rivalries, threatened employment opportunities for incumbent officials, the loss of union identity, ideological incompatibility ${ }^{2}$ and organisational jealousies, quite apart from the exacting legal requirements applied to organisations seeking amalgamation under the Federal Conciliation and Arbitration Act, ${ }^{3}$ are but some of the factors militating against formal mergers.

However, despite these factors and the dearth of actual amalgamations, the rationalization of Australian union structure is by no means a dead issue.

\footnotetext{
Industrial Relations Programme, University of Melbourne.

This does not include amaigamations achieved under State industrial legislation. nor are "living together" arrangements includ ed.

2. See, B. Carr, "Australian Trade Unionism 1977". The Journal of Industrial Relations, Vol. 20(1) March 1978, pp. 80-81 for a brief account of an unsuccessful attempt to merge the New South Wales Branches of the Australian Workers Union and the 3. D. Khoury. "The Federal Law Relating to Union Amalgamation in Australia: Help or Hindrance?", The Journal of Industrial Rela-
tions, Vol. 20 (1). March 1978, pp. 56-64.
} 
Serious negotiations on amalgamations (some already culminating in memorandums of agreement or understanding) are proceeding between the Australian Textile Workers Union (26,108 members) and the Australian Boot Trade Employees Federation (7,680 members); The Seamen's Union of Australia (4,625 members) and the Marine Cooks, Bakers and Butchers Association $\left(500\right.$ members): ${ }^{4}$ the Federated Ironworkers Association $(58,719$ members)and the Australasian Society of Engineers $(21,703)$; the two major distributive unions - the Federated Storeman and Packers Union of Australia $(62,000$ members) and the Transport Workers Union of Australia $(65,829$ members); and the strategically placed Amalgamated Metal Workers and Shipwrights' Union (131,029 members) and the Federated Engine Drivers and Firemens Association of Australia (26,769 members). ${ }^{5}$ The issue of "one union on the waterfront" is also currently being pursued on Australia's wharves $^{6}$ and a special amalgamation conference has been conducted by the leading unions in the postal and telecommunication divisions of the public service? $^{7}$

Perhaps more importantly, however, recent events on the peak union council level have provided a major boost to further rationalization in union structure. The creation of a single peak union council in Australia came a step closer to fruition on December 4, 1979 when the Australian council of Salaried and Professional Associations (ACSPA), Australia's largest white collar peak council, was dissolved to complete a unification proposal between itself and the ACTU.

The foundations for the merger of Australia's two largest peak union councils had been laid over a ten-year period but concerted activity was largely confined to the two years following the ACTU's 1977 biennial Congress when the Council agreed in principle to changing its structure to accommodate ACSPAaffiliated unions within its ranks. In short, the structural changes embraced the addition of another Vice President, Assistant Secretary and an ACSPA Group Representative on the ACTU Executive provided a sufficient number of ACSPA affiliates, representing a substantial number of members, joined the ACTU. Further, it was understood that a 'white collar' or 'salaried' secretariat would eventually be established within the ACTU.

The 1977 Congress decision placed the ball firmly in the court of ACSPA affiliates and by September 1979 all but the Australian Bank Employees Union and two State constituents of the Australian Teachers Federation - the Tasmanian Teachers Federation and the South Australian Institute of Teachers (with a combined membership of approximately 90,000) had decided to affiliate with the ACTU. Procedures for determining the question of affiliation rested with ACSPA affiliates individually and ranged from plebiscites of membership to decisions taken by union executives/conferences.

The merger was consummated during the 1979 ACTU Congress when delegates endorsed the necessary constitutional changes. It could be argued that as ACSPA had only brought in approximately 162,000 members its three positions on the ACTU Executive constituted a relatively generous deal. ${ }^{8}$ The President, however, best summed up the ACTU's attitude when he told Con-

4. See The Seamen's Journal. Vol.34(6) September/October 1979, p. 1

5. See Amalgamated Metal Workers and Shipwrights Union Monthly Journal, December 1977, p.5; November 1979 , p.8.

6. See Australian Financial Review. 20/2/80, p.44. This is not an attemptat a formal merger but a drive by the Waterside Workers Federation to sign up all watertront employees

7. See The Communication Worker, September 1977 and also The Post. Vol. 12(4) December 1979 , pp.4 and 7

8. The original proposal of an additional Vice President was, however, modified by placing a 2 -year time limit on the new VicePresident being elected solely by ACSPA group members. Although time did not permit discussion on this item Congress was assured that the matter would be given priority by the incoming Executive. 
gress that "it was necessary to put out a sufficient enticement to get a united union movement".

The 1979 Congress also had before it a proposal to incorporate Australia's largest government employee peak council, the Council of Australian Government Employee Organisations. The foreshadowed terms of the proposed merger appear similar to those of the ACSPA unification-namely, the creation of a new ACTU Industry Group for Australian Government employees, an additional Assistant Secretary position to be filled by the incumbent CAGEO Secretary and the extablishment of a CAGEO Secretariat. However, the 'package' does not involve the addition of a further Vice-President. Many industrial observers expect that the ACTU-CAGEO unification will be finalised at the 1981 Congress.

These mergers (actual and probable) represent major developments in the rationalization of Australian union structure. The 'new look' ACTU could have up to 160 -affiliates representing a wide cross section (2.2 million) of the Australian workforce and employ five full-time officers and fifteen or so industrial staff. The mergers will provide an excellent opportunity for the ACTU to re-examine its internal executive/organisational structure. Indeed, following an unsuccessful move during the 1979 Congress to expand the current Executive to provide direct representation to unions with membership in excess of 75,000, the ACTU acknowledged that its current representation structure needed modification and agreed to review this matter and report its findings by December 1980. Greater co-ordination and impact of research, advocacy and industrial campaigns (avoiding the costly duplication of resources and effort) should also be an important by-product of the merger.

Time alone will tell the nature and extent to which the influx of substantial numbers of white collar and/or government employees will influence the ACTU's policies and internal politics. If the ACSPA's Groups's voting pattern on the Uranium issue at the 1979 Congress is any indicator, however, expectations that 'moderate' white collar unions might dilute the 'militancy' of blue collar unions may be completely unfounded.

\section{LEADERSHIP AND IDEOLOGY}

1980 will mark the departure of Bob Hawke as President of the ACTU, a position he has held since 1969; his decision to enter Federal politics has given rise to heightened interest in the Australian union leadership stakes. Whilst Hawke has been in no hurry to relinquish his post since his parliamentary preselection late in 1979, the knowledge of his imminent move has occupied the minds of union activists for many months. Hence, the more than usual excitement surrounding the ACTU Executive elections at Congress where delegates jockeyed for positions, recognizing that Hawke's successor would almost certainly (though not necessarily) come from the ranks of the Executive. In addition to the eventual determination of the Presidency, the Industry Group Representatives on the Executive were in some instances the subject of fierce, and in one case disputed contest reflecting the inevitable(?) public airing of the fragile nature of the Centre-Left coalition that had first won the Presidency for Hawke back in 1969; further, these contests highlighted the complexities of personality and ideological alliances within the Australian union scene entering the 1980's. 


\section{Congress Elections}

Obviously much of the lobbying and many of the "ticket" decisions occur prior to Congress, but the event itself provides the impetus and opportunity for direct personal contact not otherwise easy among delegates from all parts of Australia. As a result, there is a succession of meetings involving from two to hundreds of delegates and held in circumstances ranging from open, to semisecret, to positively clandestine, in venues which include Congress hall corridors, individual union headquarters, hotels, restaurants, private homes, street corners, even toilets. So it is that some nominations are not decided until the eleventh hour and after much agonising as was the case at the 1979 Congress when the Left eventually chose their candidate for the position of Junior VicePresident - a decision that was taken after a hectic, noisy Centre-Left caucus the night before the closing date for nominations.

Independently of ACTU Congresses, each affiliated Trades and Labor Council (six in all) appoints a representative to the ACTU Executive. Congress elects the remainder of the positions. The Executive of 18 was increased at Congress by three new positions (a Vice-President, an Assistant Secretary and a Group Representative, with provision for a change in the rules in 1981) to accommodate the ACSPA presence in the ACTU. (See above for details).

The filling of the two remaining Vice-Presidential positions provided much interest. In recent years these contests have tended to be close affairs especially as they are widely regarded as providing a presidential heir apparent. The 1979 elections were no exception. For the two positions there were four candidates and three how-to-vote cards roughly equating the Centre, Left and Right forces. (These distinctions are, of necessity, over-simplifications and are complicated by the reluctance of groups to constantly and openly wear such labels, often preferring terms like "progressive" and "moderate". Further, there are the vagaries of personal loyalties and animosities which defy ideological categorisation. However, overall, this distinction seems close to the line-up of forces. The eventual outcome was as follows: Senior Vice President-Cliff Dolan (the incumbent); Junior Vice President-Jim Roulston (Junior Vice President in 1975, defeated in 1977).

An indication of the changed balance of political forces that was a feature of the 1979 Congress was the failure in this contest of Hawke's "man' "Charlie Fitzgibbon. The Left was jubilant as the result was exactly in keeping with their ticket.

The election of Group Representatives held few surprises except for the drama (melodrama?) that surrounded the Building Group contest, the initial result being challenged on the basis of irregularities in the number of votes cast. A second poll was held after a stormy debate and intense lobbying, union style, including at least one "punch-up". The initial result was reversed giving Builders Labourers Federal Secretary, Norm Gallagher a place on the ACTU Executive after several years absence. ${ }^{9}$ Interestingly, here, as on previous occasions, the contest was between Left-wingers - a further expose of the myth of Left homogeneity in the Australian union scene; indeed, the internecine ideological war rages unabating.

9. Rival Communists, Norm Gallagher and Pat Clancy (Building Workers Industrial Union) had vied with each other in very close contests for the ACTU Executive spots in recent years with honours going more often to Clancy. On this occasion, Clancy did not stand for the position because of ill-health. 


\section{The Balance of Forces}

Analysts have been almost unanimous in hailing the 1979 ACTU Congress as an unequivocal shift to the Left - the success of Left candidates combined with the important victories of Left-Centre sponsored policies adopted by Congress (most notably the decision on uranium)-encouraged this assessment. But such an appraisal should be tempered by recognition of the extremely good showing by McMahon, the Right's Vice-Presidential candidate, who, though hardly known in union circles prior to Congress, is seemingly being groomed as the Right's chief union spokesman; his was quite an impressive debut and the degree of support he mustered might well be interpreted as a consolidation of Right-wing forces even though their position still remains a minority one. However, combined with some Centre groupings, they can become the dominant group in much the same way as the Left achieves dominance. (The Rightbacked successful opposition to the Executive's attempts to substatially increase capitation fees from affilitated unions demonstrated this). Further, the replacement of Clancy by Gallagher is not a simple replacement of like-minded "Lefties". Both are Communists, but of very different varieties (popularly differentiated as pro-Moscow versus pro-Peking). Gallagher has already shown that he is not totally unwilling to align with the Centre-Right rather than the Centre-Left forces on the Executive. ${ }^{10}$

Perhaps the infusion of the "new breed" of union activists from the ACSPA ranks has generated more support for avant garde policies usually associated with the Left. Certainly, the ACSPA delegates almost unanimously supported the Left's position on uranium, eliciting some rumblings of discontent among sections of the blue-collar brigade. The ACSPA personnel on the Executive might reasonably be expected to side with the Centre-Left on most issues. The Left was also strengthened by the impressive performance of the representative of the West Australian Trades and Labor Council, Peter Cook, who left a decided mark on Congress with the dramatic instances of union-government confrontation in West Australia where unionists had been arrested and faced possible gaol sentences for engaging in illegal assembly. Cook appeared to cement his power base and emerged as a persuasive leader, not as powerful or as impassioned as the more experienced John Halfpenny (AMWSU) but "untainted" by Communist connections" 11 - a decided plus for the Left.

Overall, there appears to have been some polarisation of the Left and Right, both of which on a number of occasions were unable or unwilling to compromise with the Centre. At the same time, on substantive policy issues, the Left appears to have more accurately read and led the mood of Australian union activists at this point of time.

Cutting across ideological lines which are at best smudgy, has been the emergence of "the professionals" or, less kindly, "the young Turks" within the leadership of Australian unions and their peak councils. Less tied to fixed positions, less bound by specific organizational loyalties yet with a general affinity for "the labour movement", this group possesses much sought after skills in research, presentation, advocacy etc. Jan Marsh (ACTU Advocate and Research Officer) and her ACTU staff colleagues exemplify this trend which is spreading across individual union organizations and is not confined to the

10. Gallagher supported Hawke's recommendation to the ACTU Executive meeting in Melbourne in February 1980 which took a strong stand in opposition to the Soviet Union's actions in Afghanistan. The Centre-Left proposed a much milder stance. Eventually a compromise resolution was adopted.

11. A long standing member of the Communist Party of Australia, Halfpenny resigned his membership early in 1980 but without de. nouncing the Party. 
white-collar/professional areas. Already, the quality of union position papers, submissions and policy recommendations has improved markedly as a result of their inputs. The next decade should see their presence even more noticeably to the fore, rather than behind the scenes as has often been the case in the past.

\section{Hawke's Swan Song-A hard act to follow}

Whilst it is interesting to speculate on Hawke's likely successor (Senior VicePresident Dolan is the hot favourite), more pertinent, surely, is how effective the new President will be. The 1979 Congress saw Hawke lose his former, almost iron grip on the Australian union movement. The media reported his being repeatedly "rolled" by Congress and more sober evaluations claimed that failure was possibly "the principal theme" of the President's last Congress, "his unhappiest". ${ }^{12}$ Despite the hard evidence of successful policy initiatives and consensus largely attributable to him personally - the ACSPA-ACTU merger, Economic Policy and Wages and Working Conditions Recommendations, etc. - his waning personal prestige at Congress encourages the view that his successor might choose to adopt a markedly different leadership style to win the respect of Australia's union leaders and rank and file unionists. More than a decade of dynamic, charismatic, sharply intelligent, at times abrasive, leadership has possibly run its course.

Interestingly, Hawke, himself, has appeared somewhat reluctant to deliberately stem the tide of unpopularity within the ACTU or, at least, has seemed insufficiently enthused to labour hard at ensuring that he leaves the union scene on a high note. How else explain the many recent personal rebuffs? It should be remembered that Hawke, for all his skillful pragmatism and undoubted political acumen, has a reputation, not newly acquired, for standing on principle, even when the odds are not in his favour. (His stance on international affairs repeatedly bears witness to this). What he has apparently lost is his almost infallible power of persuasion at Congress which, until 1979, could be regarded as unmatched. It may well be that Australia's leading unionists believed that Hawke was pre-occupied with his future non-union rule and in that context they decided to 'switch off" or, alternatively, to "switch on" less emotionally, more soberly. However many dimensions there are to the Hawke/ACTU era, the new President appears to be confronted with two clear options - to attempt to emulate his colourful predecessor or to work at establishing a completely different image of a capable front man for a collective leadership; the former course would seem to be unlikely, in the short term, at least, while the latter is frought with all the pitfalls that beset anyone undertaking the formidable task of representing a consensus picture of what is basically an ideologically divided body of powerful union leaders. Little wonder that the hunt for a new President has already caused considerable frustration leaving a path strewn with casualties, scratchings and non-entrants long before the course has been completed.

\section{POLICY ISSUES}

The almost universal appraisal by non-union observers of the leadership changes in the ACTU as a substantial victory for the Left was accompanied by a chorus of voices regaling the unions for formulating an array of "unreal"

12. R.M. Martin, "The ACTU Congress of 1979", Journal of Industrial Relations, Vol.21, No.4, December 1979, p.495. 
policies. The major daily newspapers, radio and television programmes, government and industry spokesmen accused the unions of irresponsible indulgence in economic and political fantasy in much the following terms:

If the potential ramifications were not so serious, the policies adopted at the weeklong ACTU Congress could be dismissed as an amusing exercise in speculative political fantasy. They have no basis in reality and no chance of being implemented.

In their rhetorical exuberance, many delegates simply ignored the real implications of inflation, unemployment and other great problems confronting the union movement in order to indulge in speculation about the best of all possible union utopias.

The result was open-ended demands for more pay for less work while denying industry access to the new technology and cheap energy which eventually might make more pay and less work possible. And they are full of carefully prepared excuses for strikes and disruption.

It is a charter for union irresponsibility. The problem is that it provides the militant minority with a ready-built platform to be exploited for their own selfish interests regardless of the costs to the community and other union members . . .13

How accurate the above evaluation is, may best be determined by a review of the major policy of the ACTU.

\section{Wages and Working Conditions}

Compared with the 1977 Congress, when the ACTU's wages policy was endorsed but barely discussed by delegates, 1979 saw a sharp focussing on this increasingly vexed area. A number of powerful individual union affiliates had made no secret of the fact that they considered the wage indexation guidelines $^{14}$ to be unworkable and that with the fall in real wage standards they were more than ready to circumvent the system and rely on direct negotiations with employers.

The Executive, alert to the immediacy of the issue, had prepared a lengthy document of recommendations on Wages and Working Conditions which included a reaffirmation of the ACTU's support for unions negotiating or bargaining for wage increases above the minimum award rates as an important avenue of wage determination. The recommendations also reaffirmed the Council's belief that the restoration and maintenance of the real level of wage rates was best achieved by quarterly rather than half-yearly as is presently the case)

13. The Victorian Chamber of Manufacturers, VCM file, Vol. 24, No. 35. September 21, 1979.

14. For a recent account of the indexation guidelines see, D. Plowman, "National Wage Determination in 1978 ," The Journal of Industrial Relations, Vol. 21(1). March 1979, pp. 78-88. 
cost of living adjustments based on the published six Capital City Consumer Price Index figure. A move by the AMWSU to persuade Congress to totally ignore the wage indexation guidelines was rejected mainly on the grounds that the smaller, weaker unions depended on the formula for gaining increases, however meagre. Neverthless, the Executive and Congress did accept an AMUSU proposal to launch a national wage case based on productivity increases since 1973/1974: a proposal which will test a previously unused tenet of the wage fixation principles. In the light of combined Federal government and employer commitment to an alternative wages strategy, the ACTU's wages package seems destined to guarantee substantial industrial upheavals during 1980, the ingenuity of the Australian Conciliation and Arbitration Commission notwithstanding.

The major thrusts of the Council's deliberations on the much-aired issue of a reduced working life centred on the shorter working week, a reduced working period over a fortnight or a month, increased annual leave, voluntary early retirement and increased long-service leave. Importantly, the possibility of unions successfully negotiating a shorter working week was deliberately linked to the necessity for workers to reap the benefits of increased leisure time rather than opting for overtime which defeats the purpose of claims for a reduction in working hours.

On a related matter and in an effort to cater for the many unionists working part-time and for many others seeking such employment, Congress warned of the dangers in allowing the creation of this form of work at the expense of fulltime jobs, i.e. it "should not be viewed as a substitute for economic policies". No worker, it was argued, should be forced into part-time employment but there should be a choice to satisfy those desirous of a more flexible working life.

\section{Uranium}

It was generally believed, even by the most ardent anti-uranium lobbyists, that the pro-uranium forces, led by Hawke with the backing of the Executive, had the numbers to carry a resolution confirming union opposition to any further development of the uranium industry in Australia whilst accepting uranium mining operations at the existing sites of Ranger, Mary Kathleen and Narbalek. The issue was undoubtedly the feature act in the week-long congress programme. Delegates seemed to be conscious from the beginning that all the other issues, with the exception of the elections, were, on emotional grounds, at least, simply preliminaries to the main bout. And bout it was. With unsavoury appropriateness, the uranium issue, as in 1977, was explosive.

The debate lasted for several hours involving 14 speakers, a majority of whom had participated in the 1977 deliberations on the same issue. The Right, led by the Australian Workers' Union, argued the need for stronger commitment to the uranium operations largely on the.grounds that unionists were already working in the industry and that Australia had a good safety record in the area. The Left-Centre anti-uranium unions moved an amendment to the Executive's recommendation which proposed "continuing opposition to the mining and export of uranium and the present programme of development" - a proposal directly in line with official ALP policy. Senior Vice-President Dolan moved the amendment amidst loud applause but again, as in 1977, the debate was virtually between Hawke and Victorian AMWSU Secretary, Halfpenny. The President ridiculed his opposition's stance as "a sloppy exercise in ineffective 
morality". Arguing the unreality of unions maintaining official bans on work that was clearly proceeding. Hawke warned that the unions were spawning a "national Newport". ${ }^{15}$ Convinced of the correctness of the Executive's position, Hawke savagely berated his opponents and resorted at times to personal jibes which were demonstrably unacceptable to the majority of delegates.

Halfpenny matched Hawke's eloquence and concentrated on emphasizing the documented evidence of nuclear power station accidents, the lack of safeguards and the general danger of the nuclear power industry to Australia and the world. Other major arguments raised in the debate included concern for the infringement of Aboriginal land rights and the need for the ACTU to conduct a vigorous campaign to educate workers on the issue. (Reference was made to the President's less than enthusiastic commitment to the implementation of the ACTU's uranium policy since 1977). Executive Members supporting Hawke questioned the legitimacy of unionists not involved in the industry determining a policy that would effectively deny jobs to other unionists; Fitzgibbon, for example, scathingly chastised those who would "fight to the last drop of blood of the wharfies" - a sentiment that was directed more at the new ACSPA affiliates than any others. In the corridors during and after the debate barbed rhetorical questions such as, "How many bloody teachers are employed in the mining industry?"' were raised in deliberate reference to the ACSPA delegates. Interestingly, fraternal delegate, Jim Knox (New Zealand Federation of Labour) addressing Congress added his voice in opposition to the uranium industry, reflecting the keenness of the anti-nuclear feeling within New Zealand labour circles.

In the end, the Left-Centre amendment was passed by 512 to 318 votes - a stinging rebuff to the Executive and to Hawke. The almost unanimous voting of the ACSPA affiliates with the anti-uranium bloc did not go unnoticed-a portent of things to come in the general area of "non-industrial" issues?

\section{Economic Policy}

Economic policy determined at Congress varied little from the ACTU's former position. The major thrust of the policy was to sheet home the blame for economic ills (inflation and unemployment particularly) on the Federal Government, to emphasize the need for business accountability, greater public equity and to assert the need for government control over prices and non-wage incomes-a policy that had been side-stepped by the ALP at its Federal Conference some weeks before Congress; in the event of a federal ALP government, this latter decision could be a source of friction within the labour movement.

Special measures concerning taxation were adopted including support for a broadly based wealth tax and capital gains tax, legislation to close tax loopholes encouraging company tax avoidance and the introduction of tax indexation. The ACTU also argued the need for governments to devise taxation policies likely to create employment. In general it was a "make the rich pay" approach.

Considerable emphasis was placed on the desirability of longer-term economic planning especially regarding the manufacturing sector of industry, manpower policies and structural adjustment.

15. A reference to the, to date, eight years-long union bans on the building of a Power House in Newport (Victoria) in the face of its actual construction. See Les Cupper and June Hearn, "Union Involvement in 'Non-Industrial' Issues: The Newport Dispute $1971-78^{\prime}$, in G.W. Ford, J.M. Hearn and R.D. Lansbury (eds), Australian Labour Relations Readings, 3rd edition, MacMillan, 
Multinationals came under close scrutiny but were not the subject of an allout attack; the focus was on national and union control machanisms to avoid unfair economic practices and/or political interference in local affairs. Whilst accepting the dual public/private economic mix, the ACTU stressed an enlargement of the public sector and, specifically, the extablishment of a National Enterprise Board. A number of amendments to the Executive's lengthy recommendations on Economic Policy were accepted and this was perhaps the topic that produced the highest degree of consensus, a notable exception here was the rejection of a Left move to affirm the socialization of industry declaration in the final resolution.

In all, the policy was largely a re-statement of earlier recommendations and its solid support was possibly the most encouraging aspect of Congress from the unions' viewpoint for it represented a united front in the face of critical economic times ahead. Whether or not such unity can be sustained for long remains to be seen. Already since Congress, there have been serious criticisms of the multi-national vehicle building industry which has retrenched many workers in recent months; developments such as these will test the strength of the apparent unified union stance on economic questions.

\section{Industrial Legislation}

Significantly, the ACTU in 1979 saw fit to feature its attitude towards the Australian system of conciliation and arbitration in industrial relations.

Aware of the attacks, mainly from government circles, on the tribunal system of dispute settlement, Congress firmly supported the concept of conciliation, first and foremost. It was sharply critical of the overly legalistic nature of the system and stressed the need for more industrial, social and economic research to be made available to conciliators and arbitrators. Penalties and sanctions against unions pursuing legitimate claims were totally rejected, as was the Industrial Relations Bureau-a much stronger ACTU stance than previously when the Bureau had been accepted with provisos; in 1979 it clearly bore the stamp of "persona non grata" as it were.

Detailed resolutions on the various State and Federal legislative measures designed to curb union power was a clear indication of unionists concern with governments' industrial "police" activities. Congress indicated its preparedness to run the gauntlet by declaring "its full support for any union or unionists acting in accordance with the decisions and rules of the union made the subject of the operation of these sanctions"'. The plethora of sanctions currently available in the Conciliation and Arbitration Act, the Trade Practices Act and the option of recourse to the civil courts provides ample opportunity to test the ACTU's resolve.

\section{Social Welfare}

Little that was new in principle emerged from Congress on this issue; the underlying theme in all the specific recommendations concerning welfare services was the plight of disadvantaged groups - the unemployed, the sick and disabled, the aged, women, migrants, low income families, Aborigines and lone parents.

16 For details of the Industrial Relations Bureau and other recent legislative developments see R. Mitchell, "Industrial Relations Under a Conservative Government: The Coalition's Labour Law Programme", The Journal of Industrial Reiations. Vol.2 1(4) December 1979 , pp. 435.465. 
Arguably long-overdue, the ACTU accepted the responsibility in a direct way for assisting disadvantaged groups. Trade unions were called upon to make their organizational and administrative resources available to assist in the provision of welfare services and to support action programmes. For the unemployed, particularly, this is a welcome breakthrough as the unionised sector of the workforce has often tended to be indifferent to their needs.

The issue of superannuation also received closer attention. Proceeding on the basis that access to an adequate standard of living on retirement and protection for dependants against the loss of family income in the event of death or incapacity are basic economic rights, Congress endorsed the call for the introduction of a portable National Superannuation Scheme providing both protection against inflation and adequate employee vesting rights. ${ }^{17}$ As a fallback strategy (and in all probability the actual strategy) Congress requested affiliates, either individually or collectively, to develop superannuation plans and "labour market insurance cover" which encapsulate the principles of "right rather than privilege"', portability, benefits vesting immediately with the employee (as a capital asset) and employee involvement in the management of the funds - principles which identify current union (and to some extent wider community) misgivings over many existing superannuation arrangements

The ACTU's policy moved a step (albeit small) closer to implementation in the months following Congress when the incoming Executive ${ }^{18}$ directed the Council's Superannuation Committee to develop a trust deed for a National ACTU Superannuation Scheme and to undertake an 'awareness' campaign among affiliated unions. Some unions have already moved on the issue. In 1978, the Federated Storeman and Packers Union was engaged in a major industrial dispute with a leading retailer to improve payout and other benefits in its superannuation scheme. On a different tack the Printing and Kindred Industries Union is currently surveying its membership to determine the feasibility of the union establishing a National portable superannuation programme. ${ }^{19}$ Although it is still "early days", it is the authors' opinion that increased union awareness of pension funds deficiences and the labour market dislocation expected to result from the introduction of "new" labour saving technology, will ensure that 'superannuation' will assume greater prominence as a union-management issue in the coming years.

\section{Technological Change}

Against a background of actual and feared job displacement through technological change, and the prevailing depressed economic circumstances, it came as no surprise when the 1979 ACTU Congress devoted considerable time to discussing its most comprehensive policy yet on this iusse. Whilst the ten-page policy defies a brief and adequate precis, the following observations seek to highlight the main thrust of the Council's deliberations.

The ACTU argues that technological change must be conceived in terms of optimum development rather than so-called maximum development ("optimum development must take into account all the sociological and environmental factors as well as economic values" ) and places priority on establishing (a) a structure for tripartite consultation (b) a program for research into future trends in technological change and the effect on workers, and (c) procedures for

17. The Executive Policy Recommendation on Superannuation was modified to encompass a Federated Storeman and Packers Union sponsored amendment.

18. ACTU Executive Meeting. October/November 1979

19. See Printing Trades Journal, January 1980, p. 2. 
notification of proposed changes, for retraining and for minimum standards of compensation in cases of unavoidable redundancy.

The consultation envisaged by the ACTU centres of tripartite committees at national, corporate and industry levels. It is contemplated that the committees, comprising representatives of the principal interest groups affected, would allow a rational consideration and planned introduction of technological change. In keeping with traditional policy individual unions are encouraged to seek obligations (via awards and agreements) from employers to consult and negotiate on issues arising from technological change. A new and imaginative dimension to its policy required the ACTU to press for the enactment of a Technological Change (Impact of Proposals) Act. This Act would require employers to specify (among other things) details of, and the reasons for, the proposed action; provide information and technical data adequate to permit a careful assessment of the proposed action; and describe and analyse the effects and costs of any redundancy upon the community, government services and welfare benefits. Employers would also be obliged to consult with the government and unions following the release of the impact statement.

On the subject of redundancy the policy specifies some thirteen compensation standards for displaced workers, including: a minimum period of six months notice for those to be retrenched; severance pay for retrenched workers based on a minimum of four weeks pay in respect of each year of employment (an extra week's pay for each year of employment for each person over 35 years of age, and an additional four weeks pay for each two years of employment or part thereof in excess of 10 years employment if over 45 years of age); portability of accrued rights including long service leave and superannuation; the implementation of union approved retraining programmes and compensation by employers to employees for capital loss in homes where such employees have to transfer to other localitites to obtain work.

Finally, in outlining the salient features of the policy, mention should be made of the successful, though largely impractical, amendment to the Executive Recommendation calling on the Council to initiate an international conference to consider imposing a five year moratorium on technological innovation involving job displacement and the Council's intention to review progress in the implementation of its overall policy at its May 1980 Executive Meeting. A campaign of non-co-operation in the introduction of new technology will be considered in the event of an unfavourable review.

The ACTU's concern over the unplanned introduction of new technology reflects the recent heightened interest in technological change among many Australian unions. Despite an abundance of policy statements to the contrary, Australian unions generally have been slow to take up the challenge presented by management-initiated investment in labour saving technology. As a general rule, employees, through their unions, are only involved in the process of change at the discretion of the party proposing the change. ${ }^{20}$ There are of course some notable departures from the norm. ${ }^{21}$ In part, the 'lip-service' only posture of the union movement stems from the long periods of low unemployment and the availability of alternative employment for displaced workers. In recent years, particularly the late 1970's, the high levels of unemployment and the potential for considerable dislocation from the advance of micro-electronics

20. See K. Pauncz, "A Survey of Redundancy Procedures", Work and People Vol.5(1) 1979, pp.7.12.

21. The Federated Clerks Union of Australia, for example, established in 1962 the right of employees and their unions to be controduce new equipment. See Federated Clerks Union v. Golden Fleece Petroleum Ltd. and Others. 122 CAR 339 . 
have forced wider acceptance among unions of the view that the introduction of new technology must be monitored/regulated more closely if its positive attributes are to be exploited and industrial and social discord avoided.

To date, the renewed union interest in technological change has been largely confined to (necessary) educational campaigns designed to raise membership, public, and community awareness of the dangers of the uncontrolled introduction of new technology, ${ }^{22}$ stoppages and threats of cessation of work over the introduction of new equipment. As yet, few unions have succeeded in eroding the belief that the timing and introduction of new technology is purely a matter for management's consideration. An exception, however, is the telecommunication industry where draft procedures for the introduction of new technologies have recently $(1978-9)$ been negotiated. ${ }^{23}$

The procedures, considered by some industrial observers as a possible blueprint for the future, represent the end product of over seventy meetings between Telecom unions and management and a mutual desire to avoid a repetition of a bitter dispute in 1978 over the introduction of new equipment. In essence, the three-year agreement attempts to establish explicit rules for considering, assessing and deciding on new technology. Specifically it provides for consultation (beginning at the "contemplative" stage and ending with the "trials and implementations" stage), jointly administered feasibility studies (including reference to the impact of the changes on staff and the community). the sharing of information, joint consideration of the timing of the proposed change, and an obligation on Telecom to pursue policies which will lead to the creation of additional employment within Telecom and associated Australian industries. The success, or otherwise, of the agreement is likely to have a marked effect on the wider acceptance of the broad principles underlying current union thinking on the vexed issue of technological change. In the absence of agreed procedures governing the introduction of new technology, serious and protracted industrial disputation will be difficult to avoid.

\section{Occupational Health and Safety}

The 1979 ACTU Congress witnessed the Council's first major pronouncement on occupational safety and health. Whilst the policy may be interpreted as being 'forward looking' in nature, it is also an explicit indictment of prior inactivity or ambivalence on the part of the union movement. Sporadic industrial action aside, Australian unions, generally, have tended to play a passive role on occupational safety and health matters, having seen fit to negotiate special penalty rates for hazardous work, and/or reserving their energies for fighting 'ex-post' compensation cases. ${ }^{24}$

The ACTU's comprehensive policy statement seeks, as its principal objective, "to provide a fundamental right to safe and healthy work". More specifically, the policy highlights what the ACTU sees as current limitations in the area, viz, the fragmentation of law governing occupational safety and health, inadequate public information, research and accountability and the need for the trade union movement to accept an increasing responsibility in the field. By way of remedy, the policy calls for uniform national standards, the

22. Two major banking unions, the Australian Banking Employees Union and the Commonwealth Bank Officers Association have been active in this regard. See, "The Banking Industry - The Myths Exploded - The Impact of Technological Change and Ra. tionalization in the Banking Industry"; pamphlet, June 1979.

23. See also the 1979 agreement between the Printing and Kindred Industry Union and the Metropolitan Daily Newspapers.

24. Not all unions have pursued these courses of action. See for example, L. Cupper, "The Meatworkers Health Clinic: Some Relevant Aspects of a Union Enterprise," The Journal of Industrial Relations, Vol. 17(4). December 1979, pp 335-344. 
creation of a National Health and Safety Office, public funded research, a common recording basis for health and safety statistics and substantially increased government - sponsored education and training in accident prevention and occupational health. ${ }^{25}$ The policy also details management and union responsibilities in the provision and maintenance of a safe and healthy workplace. It is of note that the ACTU, in conjunction with CAGEO, (if resources permit) is directed to establish an Occupational Health Unit to undertake information dissemination, monitoring, research and liaison functions.

Unquestionably, the ACTU has plotted an ambitious charter but also one capable of attracting widespread union support in an environment characterized by a rapid acceleration of the use of new chemical substances and the development of new technology. Increasing interest in occupational safety and health is certainly not confined to peak union council policy statements. For example, the Victorian Trades Hall Council is currently funding a small Occupational Health and Safety Centre; unions representing a broad cross section of the ideological spectrum have recently undertaken a sustained and concerted industrial campaign over the Victorian Government's controversial amendments to the State's Workers Compensation Law; the NSW Labour Government has launched an inquiry into. occupational safety and health; and the Australian Trade Union Training Authority has drawn on both local and international expertise to conduct special training programmes for union officials on hazard recognition and abatement. These and other signs suggest that the unions will give the general field of occupational safety and health higher ranking than in the past.

Due to Congress time-table pressures, some issues, including Industrial Democracy, Working Women's Policy, the Arts and Creative Recreation, Disadvantaged Minorities, and others were not debated. It can be reasonably assumed that the executive recommendations in these areas were not contentious. Many of these issues had been canvassed previously and others may not be deemed to be of top union priority - a fact that some critics would bemoan but in terms of the availability of resources and time and the degree of commitment among unionists, a seemingly not altogether unfair assessment.

\section{A Concluding Note}

Many of the union policy initiatives outlined in this paper explicitly recognise the need for the support of trade union and community education if they are to be successfully implemented. Accordingly, it is pertinent to close this broad overview of cross-currents in Australian unionism with a brief account of recent developments on the trade union education front.

The arrival of the Australian Trade Union Training Authority, a public funded Statutory body, has changed dramatically the face of trade union education in Australia. The Authority (known as TUTA), established by the Whitlam Federal Labor Government in September 1975, is formally charged with the responsibility of providing, co-ordinating and promoting union education. ${ }^{26}$ Its creation marked an end to years of ad hoc and piecemeal training activity and presented Australian unions the opportunity to overcome the considerable han-

25. The dearth of training facilities and data on industrial or occupational injury has aiso been noted by Prof. L. Opit, Chairman, Department of Social and Precentive Medicine, Monash University. See L. Opit, "Work and Health: The Australian Perspective" Proceedings, Occupational Safety and Health Conference, February 19, 1980, CHH Industrial Relations Consultants, Melbourne.

26. For a fuller account of the developments and activities of TUTA, see Les Cupper, 'Public Funded Trade Union Education: The Australian Experience", Industrial Relations Journal, Vol.Il(1) March/April 1980. 
dicaps then inhibiting training programmes: viz., the irregularity of the courses, union apprehension, lack of continuous contact between instructors and the unions, and limited resources, facilities and equipment. Union training had also lacked co-ordination and direction - a fact that caused some sympathetic educationists concern. ${ }^{27}$

TUTA operates at both the State and National level with well equiped training facilities in each of the major capital cities and the National residential centre, Clyde Cameron College, at Albury/Wodonga. It currently employs approximately 80 full-time staff - one third of whom undertake the training function. The control of TUTA's overall activity is vested in a Director, an Executive Board and a network of Councils comprising representatives from a cross-section of the union movement, and employer, government and opposition party nominees.

As its broad objective, TUTA aims to have annual course contact with one percent of Australian trade union membership i.e. on present figures, yearly contact with some 29,000 unionists. The one percent training objective (currently under review) is based on an estimate that about 5-6 percent of all unionists are "organisationally active". ${ }^{28}$ Within this general charter the Authority's programme has been 'skills' training as TUTA has tended to view union training as training and education for persons working within a specific context and serving a specific organisation (the trade union) and not as a system of general education.

Approximately 18,600 unionists from 200 unions attended the Authority's courses in the years 1975-78. By far the majority of the State level course participants held part-time or honorary union positions; less than two in ten participants were full-time officers. Predictably, a different picture emerges at the national ('advanced') level where almost sixty percent of participants in 1977-78 held fulltime office. Not only has TUTA helped to fill much of the void in union training but its presence and activities have also been instrumental in accelerating the introduction of paid education leave for union training - particularly in public sector employment. ${ }^{29}$ Although paid education leave is not a common standard in the private sector, a combined union case is currently before the Australian Conciliation and Arbitration Commission on this issue. Any growth in paid education leave resulting from this case would be welcomed by unions and the Authority alike as access to such leave has been a major factor in determing attendance at TUTA programmes. Further, recent appointments of full-time Education officers, and the consequent growth in training conducted by individual unions ${ }^{30}$ can be attributed to TUTA and union recognition of the need for complementary broad - based education programmes for rank and file unionists unlikely to attend TUTA programmes. In part, these appointments can also be seen as attempts by some unions to establish union controlled, self-funded training programmes to avoid being totally reliant on public funded training susceptible to the whims of the government of the day.

The picture painted so far suggests that TUTA is widely accepted by a broad cross-section of the Australian labour movement and all augurs well for the future. However, despite the Authority's most promising beginnings, its future,

27. See P.W.D. Matthews and G.W. Ford, 'Trade Union Education and Training in Australia' The Journal of Industrial Relations. Vol. $8(2)$, July 1966 , pp. 158-174

28. See P.W.D. Matthews, "The Influence of Trade Union Training on Union Organisation" 48th ANZAAS Congress, Melbourne, August 1977.

29. Each State Public Service, except Queensland, provides paid educational leave for union training, as does the Australian Government Public Service.

30. For example, The Municipal Officers Association, the Federated Clerks Union, The Australian Insurance Employees Union, The Australian Public Service Association, the Vehicle Builders Employees Federation to name but five unions. 
and the future form and direction of Australian union training, remains clouded. This situation results from the Liberal and Country Party (LCP) Coalition Government's August 1978 controversial amendments to the Trade Union Training Act, amendments that dramatically altered TUTA's organisational structure and executive control. Details of the events leading to the legislative change and the specific changes have been documented elsewhere. ${ }^{31}$ Suffice to say that the LCP retained TUTA as an independent and public funded training institution but removed union control of the Authority's Executive body. Union reaction to the amendments was predictably hostile but stopped short of either industrial action or boycotting TUTA courses. Some unions, however, have suggested that the 'emasculation' will undermine union confidence in the Authority.

If TUTA remains Australia's major provider of union training (and clearly the Authority's position is strengthened by the dearth of alternative training facilities) the fruits of its labour and the nature of its role in the implementation of union policy should become more evident in the 1980's. The impact of training on union administration, the job performance of union personnel (including the preparation and presentation of union cases and research) and employeremployee relations generally, are three benchmarks worthy of future surveillance.

31. Cupper, ibid.

\section{EDUCATION WITHIN THE TRADE UNION MOVEMENT - SOME SUGGESTIONS FOR DEVELOPMENT}

- Michael Hanne*

\section{Six kinds of trade union education}

The term "trade union education" can be used to cover quite a number of different activities. I think it makes sense to see all these activities in terms of a spectrum that ranges from the very specific training of people for a particular role within the trade union movement, through the broader area of education about the trade unions, to trade-union-based worker education in the broadest sense. Six main activities can probably be usefully distinguished within this whole spectrum:

1. the training of job-delegates, branch officers and full-time union officials in the (increasingly) complex skills they need to work effectively on behalf of their members;

2. the education of rank-and-file members about the importance and value of the union movement, its history, objectives, the main issues it faces, and about how to get the maximum benefit from belonging to a trade union;

3. the education of the public at large in the functions and importance of trade unions with the particular aim of counteracting the generally unsympathetic image of trade unions presented by newspapers and television;

- Michael Hanne is Senior Lecturer in Italian in the Department of Romance Languages at the University of Auckland 